Canadian Journal of Fisheries and Aquatic Sciences, 2003 v60, n8, p938-948.

ISSN: 1205-7533

doi: 10.1139/F03-083

http://pubs.nrc-cnrc.gc.ca/rp-ps/journalDetail.jsp?jcode=cjfas\&lang=eng

http://article.pubs.nrc-

cnrc.gc.ca/RPAS/rpv?hm=HInit\&calyLang=eng\&journal=cjfas\&volume=60\&afpf=f03-

083.pdf

(C) 2003 NRC Canada 


\title{
Understanding latitudinal trends in fish body size through models of optimal seasonal energy allocation
}

\author{
James E. Garvey and Elizabeth A. Marschall
}

\begin{abstract}
For fish at high latitudes, short growing seasons should constrain size-at-age, although the converse often occurs. We used a dynamic state variable model to find energy allocation strategies to length, fat, and ovaries that maximize expected egg production of largemouth bass (Micropterus salmoides). We determined how latitudes and rations affect optimal allocation and then simulated growth using optimal strategies. A theoretical reciprocal transplant explored how latitude-specific optimal strategies affected growth at other latitudes. At low ration, allocation and growth were similar among latitudes, with length selected in small individuals and reproductive tissue and fat in large counterparts. At high rations, low-latitude fish invested most energy to length and reproduction; high-latitude fish allocated to length during summer and fat during fall and developed ovaries earlier in the year. Transplants revealed that smaller size-at-age occurs in the north than in the south, consistent with field patterns for largemouth bass. Although northern strategies allowed fish to be successful in the south, southern strategies were unsuccessful in the north. Latitudespecific energetic adaptations may compromise success of fish transplanted beyond their native distribution.
\end{abstract}

Résumé : Chez les poissons des hautes latitudes, les saisons de croissance courtes devraient réduire les tailles à un âge donné, alors que souvent c'est le contraire qui se produit. Un modèle à variables dynamiques nous a permis d'identifier les stratégies d'allocation de l'énergie à la croissance en longueur, à la graisse et aux ovaires qui maximisent la production attendue d'oeufs chez l'achigan à grande bouche (Micropterus salmoides). Nous avons déterminé comment la latitude et la ration alimentaire affectent l'allocation optimale, pour ensuite faire une simulation de la croissance dans des conditions de stratégies optimales. Un transfert réciproque simulé a servi à explorer comment les stratégies optimales spécifiques à une latitude affectent la croissance aux autres latitudes. Lorsque les rations alimentaires sont faibles, l'allocation et la croissance sont semblables à toutes les latitudes : la longueur est favorisée chez les petits individus et les tissus reproducteurs et adipeux chez les plus grands. Lorsque les rations sont fortes, les poissons des basses latitudes investissent la majorité de leur énergie dans la croissance en longueur et dans la reproduction; les poissons des latitudes élevées allouent leur énergie à la croissance en longueur en été, aux tissus adipeux en automne et au développement des ovaires tôt dans l'année. Les transferts indiquent que les tailles spécifiques aux âges sont plus faibles dans le nord que dans le sud, ce qui correspond à la situation de l'achigan à grande bouche en nature. Bien que les stratégies nordiques permettent aux poissons de se maintenir avec succès dans le sud, les stratégies du sud ne fonctionnent pas dans le nord. Les adaptations énergiques spécifiques à la latitude peuvent donc mettre en péril les transplantations de poissons au-delà de leur répartition d'origine.

[Traduit par la Rédaction]

\section{Introduction}

Bergmann's rule suggests that the body size of animals should increase with increasing latitude (Lindsey 1966). For many widely distributed poikilotherms that grow indetermi-

Received 23 December 2002. Accepted 31 July 2003.

Published on the NRC Research Press Web site at

http://cjfas.nrc.ca on 9 September 2003.

$\mathrm{J} 17256$

J.E. Garvey. ${ }^{1}$ Fisheries and Illinois Aquaculture Center, Department of Zoology, Southern Illinois University, Carbondale, IL 62901-6511, U.S.A.

E.A. Marschall. Aquatic Ecology Laboratory, Department of Evolution, Ecology, and Organismal Biology, The Ohio State University, 1314 Kinnear Road, Columbus, OH 43212-1156, U.S.A

${ }^{1}$ Corresponding author (e-mail: jgarvey@siu.edu). nately, including fish, the applicability of this rule has been questioned (e.g., Roff 1980, 1986). These species must contend with shorter growing seasons and longer winters as latitude increases (Mousseau 1997). Warm summers foster growth, whereas cold winters may completely arrest it. As such, fish and other aquatic poikilotherms at high latitudes may have a limited opportunity for growth and, thus, may ultimately be smaller than conspecifics at low latitudes. Latitudinal differences in growth and body size should be particularly relevant during the first year of life, because increasing size often increases the probability of first-winter survival and ultimately recruitment to the population (Garvey et al. 1998).

Body size at any time is the result of interactions among energy intake, metabolic costs, and the allocation of net energy to different structures and activities. Patterns of energy allocation affect an organism's level of energy stores and degree of gonadal development. Seasonal changes in body com- 
position must occur in anticipation of conditions that affect survival or reproductive success (Shul'man 1974; Weatherley and Gill 1987; Bunnell and Marschall 2003). Energy reserves should increase before predictable times of low food availability such as winter, whereas gonads should develop in advance of the reproductive season. As individuals allocate energy to gonads or fat reserves, they necessarily reduce their allocation to permanent structural growth (herein referred to as "body size"). Because the maximum fat reserves and gonadal mass that an individual can hold generally increase with body size, by allocating energy to fat or gonads rather than body size, an individual may actually be compromising its future reproductive output potential. An appropriate balance of these options should be quite important at high latitudes as reduced temperature limits energetic intake.

Although it may be clear that seasonal changes in body composition incur fitness consequences, the issue of how body composition precisely relates to fitness is complex. For example, because of allometric morphological relationships, increased growth in length often increases fat reserve capacity while reducing mass-specific metabolic rate in fish. When energy intake is limited, energy stores are depleted less rapidly with increasing size. Conversely, accumulating energetically dense fat tissue requires a considerable energetic investment that must be met at the cost of reduced growth in length. The importance of energy stores and metabolic rate should change with latitude, as mean temperature and duration of winter change. How allocation strategies vary along environmental gradients should greatly affect growth, reproductive success, and thereby the geographic distribution of species. Indeed, seasonal patterns in body composition often vary among populations within a species and can be genetically determined (Mousseau and Roff 1989).

Given the role that energy allocation patterns may play in determining size across a latitudinal gradient, particularly during the first year of life, understanding the trade-offs that drive energy allocation will contribute to the discussion of whether and why aquatic poikilotherms should follow Bergmann's rule or its converse. Reasoning in support of a converse to Bergmann's rule for poikilotherms generally is based on the simple direct interaction between temperature and physiology: consumption and metabolic rates decline with decreasing temperature, resulting in small body size at high latitudes. Reasoning in support of Bergmann's rule generally is based on the strength of selection for large size in cold environments: either the relative advantage of large size is high or the relative disadvantages of getting to a large size are low (Partridge and Coyne 1997).

Dynamic state variable models (Mangel and Clark 1988) are perfectly suited to consider state- and condition-dependent limitations in the context of finding evolutionarily optimal responses, which maximize expected lifetime fitness. We developed dynamic-state variable models to find differences in optimal energy allocation between northern and southern latitudes of a fish with temperature-dependent consumption and growth potential. This discrete-time optimization method uses backward iteration to find strategies that maximize expected future lifetime fitness in problems involving a sequence of decisions (Bellman 1957; Mangel and Clark 1988).
We have embedded a bioenergetic algorithm within this dynamic model that calculates consumption and metabolic rates as functions of temperature and body mass (Wright et al. 1999).

Our ultimate goal was to weigh how latitudinal differences in temperature and related factors affect seasonal changes in body composition, body size, and reproductive output of widely distributed fish and other aquatic poikilotherms. We first explored optimal energy allocation patterns across a latitudinal gradient. Next, we simulated the growth that arises from these optimal patterns to compare size-at-age and reproductive potential between latitudes. And finally, we performed a theoretical reciprocal-transplant experiment by simulating the optimal high-latitude allocation patterns in low-latitude conditions and optimal low-latitude allocation patterns in high-latitude conditions. These results provide insight into patterns of growth of widely distributed species and options for their conservation at geographic scales not typically addressed by managers.

\section{Methods}

\section{Study species}

Largemouth bass (Micropterus salmoides) is a widely distributed fish species found in freshwater lakes and rivers from 25 to $47^{\circ} \mathrm{N}$ latitude in North America. As such, separate populations of this species experience very different seasonal temperatures. At any latitude, this species' distribution is cosmopolitan, including aquatic ecosystems of a variety of levels of productivity, types of prey assemblages, and combinations of physical characteristics (e.g., temperature stratification). The bioenergetics of this species are generally well understood, and underlying relationships have been incorporated into a mass-balance model that has produced robust, field-verified results (Rice and Cochran 1984). Because this model and empirical evidence demonstrate that temperature strongly influences growth in largemouth bass as well as other fishes, seasonal variation in temperature should drive much of the variation in energy allocation patterns and reproductive success throughout this species' range.

\section{Dynamic state variable model}

For each week $t(t=0,1, \ldots, 51$, where $t=51$ is the week of spawning) of each year $y(y=0,1, \ldots, 5)$ in the dynamic state variable model, we calculated the maximum expected future lifetime fitness, $F(L, w, r, t, y)$, of a female largemouth bass of body length $L$ (total length, $\mathrm{mm}$ ), having fat reserves at $w$ proportion of their maximum and having reproductive tissue at $r$ proportion of its maximum. Maximum fat reserves and reproductive tissue are assumed to be increasing functions of $L$. Some fat reserves are necessary for survival; thus largemouth bass with $w=0$ die.

For any given week, a modeled fish compares expected future fitness from each possible allocation strategy $\phi(\phi=$ $\left.\left(\phi_{L}, \phi_{w}\right)\right)$ in which the fish allocates a proportion $\phi_{L}$ of that week's net energy intake to growth in length, a proportion $\phi_{w}$ to growth in fat reserves, and a proportion $1-\phi_{L}-\phi_{w}$ to growth in reproductive tissue. On week 51 , the fish spawns, receiving a fitness payoff that is a function of the state of its 
reproductive tissue. Simulations ended after 6 years, allowing fish potentially to spawn six times.

An allocation strategy $\phi$ during a given week $t(t=0$, $1, \ldots, 50)$ by a fish having state values $L, w$, and $r$ results in state values the following week of $L^{\prime}(\phi), w^{\prime}(\phi)$, and $r^{\prime}(\phi)$, respectively. The fish chooses the allocation strategy that maximizes expected lifetime fitness beginning at the present, such that during nonspawning weeks

$$
F(L, w, r, t, y)=\max _{\boldsymbol{\phi}} F\left(L^{\prime}(\boldsymbol{\phi}), w^{\prime}(\boldsymbol{\phi}), r^{\prime}(\boldsymbol{\phi}), t+1, y\right)
$$

During week $t=51$, an allocation strategy $\phi$ results in new state values at the beginning of the next year (which begins the week after spawning) of $L^{\prime \prime}(\phi), w^{\prime \prime}(\phi)$, and $r^{\prime \prime}(\phi)$ such that

$$
\begin{array}{r}
F(L, w, r, 51, y)=Q(L, w, r)+\max _{\boldsymbol{\phi}} F\left(L^{\prime \prime}(\boldsymbol{\phi}), w^{\prime \prime}(\boldsymbol{\phi}),\right. \\
\left.r^{\prime \prime}(\boldsymbol{\phi}), 0, y+1\right)
\end{array}
$$

where $Q(L, r)$ is the reproductive output (number of eggs) from spawning at the end of year $y$.

The actual amount of energy allocated to each function is limited by the amount of food ingested in a given week. We represent energy ingested as a proportion $\rho$ of the maximum possible $\left(C_{\max }\right.$; calories'week $\left.{ }^{-1}\right)$ for a largemouth bass of that size:

$$
C_{\max }=0.33 M^{0.675_{z}} \times 7 \times 1000
$$

where $M$ is wet mass ( $\mathrm{g}$ ) excluding fat and is calculated as $M=\left(1.35 \times 10^{-5}\right) L^{2.98}$ (Trebitz 1991) and $z$ is a temperaturedependent multiplier (see Rice et al. 1983). The function for $C_{\max }$ derives from data in Niimi and Beamish (1974) that was modeled by Rice et al. (1983). We assumed a prey caloric density of 1000 calories $\mathrm{g}^{-1}$ (Wright et al. 1999). Fat could make up no more than $3 \%$ of total wet mass (Miranda and Hubbard 1994; Oster 2002), and reproductive tissue could make up no more than $10 \%$ of total wet mass (Carlander 1977). We used $W$ to represent grams of body mass in fat $(W=w(0.03 M))$ and $R$ to represent grams of reproductive tissue $R=r(0.1 M)$ ). Weekly metabolic costs $\alpha$ (calories'week ${ }^{-1}$ ) were estimated as a function of temperature $\tau\left({ }^{\circ} \mathrm{C}\right)$ and total wet mass $N(\mathrm{~g})$, including mass of the current fat and reproductive tissue, $N=M+W+R$. These variables were included in a metabolic cost function described by Trebitz (1991):

$$
\alpha=0.0868 N^{-0.355} \mathrm{e}^{0.0811 \tau+0.0196} K_{\text {act }} 0.078
$$

where we assume that largemouth bass caloric density is 1000 calories $^{-1} \mathrm{~g}^{-1}$ (Garvey et al. 1998) and $K_{\mathrm{act}}$ is an activity multiplier that causes small largemouth bass $(<60 \mathrm{~mm})$ to grow at realistic rates (Trebitz 1991):

$$
K_{\text {act }}= \begin{cases}1 & \text { for } \tau<10^{\circ} \mathrm{C} \\ 1.1 N^{-0.1} & \text { for } \tau \geq 10^{\circ} \mathrm{C} \text { and } N \leq 2.594 \mathrm{~g} \\ 1.0198 & \text { for } \tau \geq 10^{\circ} \mathrm{C} \text { and } N>2.594 \mathrm{~g}\end{cases}
$$

Weekly costs $I$ (calories'week ${ }^{-1}$ ) due to egestion and excretion were estimated as a function of temperature, total mass, and ration according to the model by Trebitz (1991):
Fig. 1. Weekly average temperatures from $(a)$ south- $\left(33^{\circ} \mathrm{N}\right.$; Ludsin and DeVries 1997), (b) middle- $\left(40^{\circ} \mathrm{N}\right.$; Garvey et al. 1998), and (c) north- (46 $\mathrm{N}$; North Temperate Lake, Long Term Ecological Research (LTER) program, 1992-1994) latitude aquatic systems. Spring (Sp), summer (Su), fall $(\mathrm{Fa})$, and winter (Wi) periods are delineated by vertical broken lines. Largemouth bass (Micropterus salmoides) at each latitude spawned at week 51 , when temperature reached $15^{\circ} \mathrm{C}$.

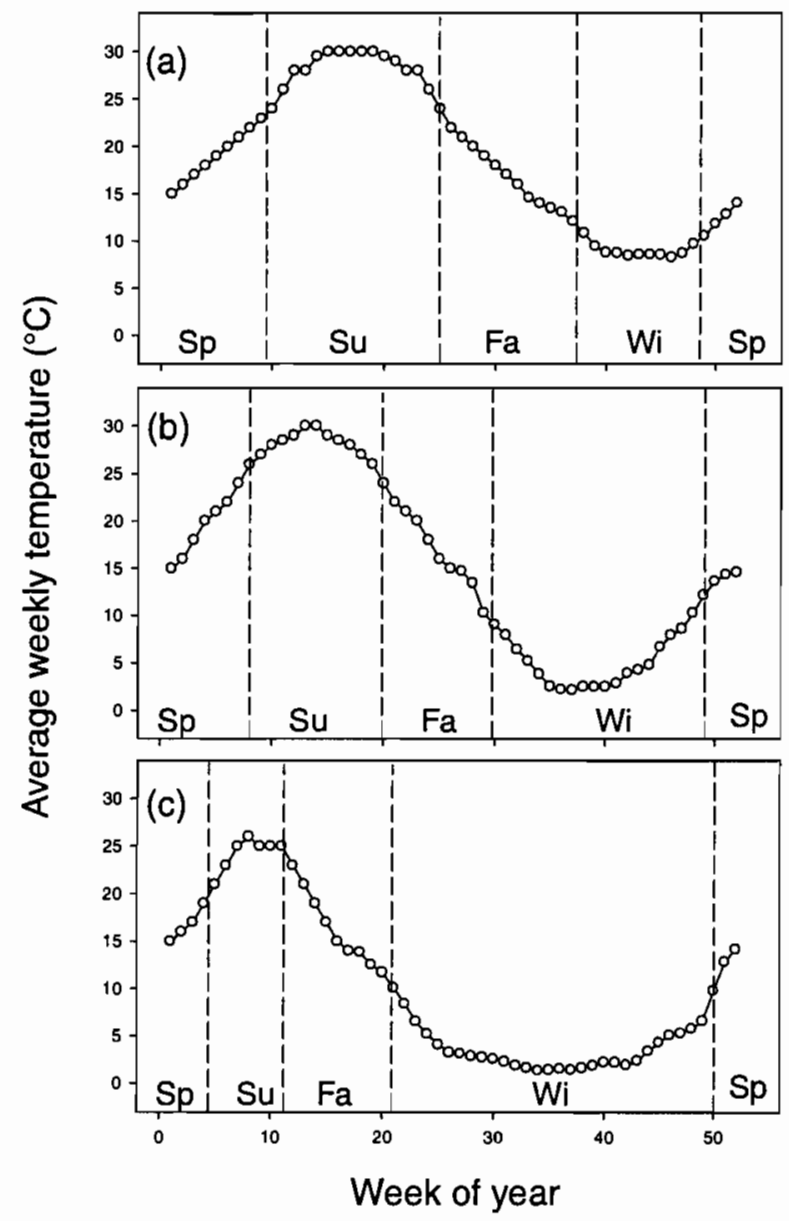

$$
\begin{aligned}
I=\left[\operatorname{SDA}\left(\tau, N, \rho C_{\max }\right)\right. & +B\left(\tau, N, \rho C_{\max }\right) \\
& \left.+S\left(\tau, N, \rho C_{\max }\right)\right] \times 7 \times 1000
\end{aligned}
$$

where SDA is specific dynamic action (calories), $B$ is feces (calories), and $S$ is excretion (calories). Again, we assumed caloric density of prey was 1000 calories $\mathrm{g}^{-1}$ and summed costs for each week. Costs of converting consumed energy into each type of body mass were assumed to be included in $I$. Weekly temperatures $(\tau)$ were weekly means measured in natural systems at southern $\left(33^{\circ} \mathrm{N}\right.$; Alabama ponds), middle $\left(40^{\circ} \mathrm{N}\right.$; Ohio reservoirs), and northern $\left(46^{\circ} \mathrm{N}\right.$; Wisconsin lakes) latitudes (Fig. 1; Wright et al. 1999).

\section{State dynamics}

We assumed that metabolic costs are paid from energy ingested each week. Costs in excess of energy consumed are paid from fat reserves. Thus, length, proportion of maximum 
fat reserves, and proportion of maximum reproductive tissue change with each nonspawning time step as a function of net energy intake (which is a function of gross energy intake, temperature, and body size) and energy allocation according to the following equations:

$$
\begin{gathered}
L^{\prime}(\phi)= \\
\left\{\begin{array}{cc}
L+\left(4.22\left(\phi_{L}\left(\rho C_{\max }-\alpha-I\right)\right)^{0.3357}\right) & \text { for } \rho C_{\max }>\alpha+I \\
L & \text { for } \rho C_{\max } \leq \alpha+I
\end{array}\right.
\end{gathered}
$$

where the coefficient (4.22) and exponent (0.3357) derive from a conversion from total calories to total length (Garvey et al. 1998),

$$
w^{\prime}(\phi)= \begin{cases}\frac{W+\phi_{w}\left(\rho C_{\max }-\alpha-I\right)}{0.03 M^{\prime}} & \text { for } \rho C_{\max }>\alpha+I \\ \frac{W+\left(\rho C_{\max }-\alpha-I\right)}{0.03 M^{\prime}} & \text { for } \rho C_{\max } \leq \alpha+I\end{cases}
$$

where $M^{\prime}$ is the somatic wet mass, excluding gonads, of a fish of length $L^{\prime}(\phi)$ and

$$
\begin{aligned}
& r^{\prime}(\phi)= \\
& \left\{\begin{array}{cc}
\frac{R+\left(1-\phi_{L}-\phi_{w}\right)\left(\rho C_{\max }-\alpha-I\right)}{0.1 M^{\prime}} & \text { for } \rho C_{\max }>\alpha+I \\
\frac{R}{0.1 M^{\prime}} & \text { for } \rho C_{\max } \leq \alpha+I
\end{array}\right.
\end{aligned}
$$

Length is truncated to a maximum of $485 \mathrm{~mm}$, because growth of largemouth bass is asymptotic. When new state values were intermediate between discrete values used in the model, we calculated expected fitness using trilinear interpolation (Press et al. 1992).

\section{Reproduction}

We assumed that fish can spawn if they are at least $250 \mathrm{~mm}$ long and $r=1$. During weeks when spawning occurs (i.e., when $t=51$ ), a spawning fish uses all of its reproductive mass such that $r^{\prime \prime}(\phi)=0$. Fitness is expressed as the number of eggs spawned.

$$
Q(L, r)=\left\{\begin{array}{cc}
g(L) & \text { for } L \geq 250 \mathrm{~mm} \text { and } r=1 \\
0 & \text { otherwise }
\end{array}\right.
$$

where $g(L)$ is the number of eggs spawned, a function of female body size $\left(g(L)=5.633 L^{1.433}\right.$; Carlander 1977).

\section{Experimental design}

Energy allocation strategies should underlie differences in growth across a latitudinal gradient. To predict how growth differs across latitudes, we used the dynamic state variable model to ask how temperature regimes associated with different latitudes (Alabama, Ohio, and Wisconsin; Fig. 1) affected optimal resource allocation patterns. We combined this with three constant-ration treatments in which fish consumed either $\rho=0.3,0.6$, or 0.9 of their $C_{\max }$ for the entire year, except when temperatures fell below $6{ }^{\circ} \mathrm{C}$ and feeding ceased $(\rho=0)$ (Garvey et al. 1998). For each latitude $\times$ food availability treatment, we calculated the optimal allocation strategy for each combination of state values: $w=0.2,0.4, \ldots$, $1.0 ; r=0,0.2, \ldots, 1.0$; and $L=50$ to 485 by $15-\mathrm{mm}$ increments. For graphical analysis, allocation results were averaged within temperature-dependent "seasons" for each modeling treatment. Seasons at each latitude were divided into winter $\left(<10^{\circ} \mathrm{C}\right)$, spring $\left(>10^{\circ} \mathrm{C}\right.$ and $<25^{\circ} \mathrm{C}$, following winter), summer $\left(>25^{\circ} \mathrm{C}\right)$, and fall $\left(>10\right.$ and $<25^{\circ} \mathrm{C}$, following summer; Fig. 1). Because this modeling exercise generated a large data array (greater than 2.9 million elements), we selected subsets of expected fitness and seasonal energy allocation results that spanned the range of state values and latitudes.

To determine how optimal allocation decisions affected patterns of growth and body size, we used the full array of decisions generated by the dynamic state variable model to simulate weekly growth of an age-0 largemouth bass with $L=50 \mathrm{~mm}, w=0.2$, and $r=0$ starting at $t=0$ and $y=0$ and continuing through $t=51$ and $\mathrm{y}=5$. Growth was simulated using the same bioenergetic routines and combinations of rations and seasonal temperatures used in the dynamic state variable experimental design. Largemouth bass greater than $250 \mathrm{~mm}$ total length and $r=1.0$ spawned at $t=51$ of each year, resulting in $r=0$ the following week. Proportional allocation decisions for length, fat, and reproductive states intermediate between values generated by the dynamic state variable model were estimated with trilinear interpolation.

\section{Theoretical reciprocal transplants}

Simulation results showed that fish grew in length more quickly at low latitudes than at high latitudes (see Results). To assess what portion of this growth difference was due to the direct effect of temperature on poikilotherm growth rates and what portion was due to optimal energy allocation responses to particular temperature patterns, we performed a set of theoretical reciprocal transplants. By "transplanting" fish with allocation responses that are optimal in the south to an "environment" (i.e., a simulation) with temperatures representative of the north and transplanting optimal northern fish to the south, we could begin to distinguish between direct effects of temperature and potential effects of evolved energy allocation responses. Using these theoretical reciprocal transplants, we simulated growth and reproductive potential of transplanted and "native" largemouth bass to help understand the factors driving latitudinal allocation and growth differences (see Munch and Conover (2002) for similar approach).

\section{Results}

\section{Optimal allocation patterns}

Expected future fitness generally declined with increasing latitude and increased with increasing ration (Fig. 2). At low and middle rations, expected future fitness increased with body size (Fig. 2).

Optimal energy allocation to length varied as a function of ration, length, fat, and latitude. At a low ration at all latitudes, optimal proportion of energy allocated to length de- 
Fig. 2. Expected number of eggs produced by a female largemouth bass (Micropterus salmoides) over 6 years as a function of latitude, total length at year 0 , and weekly ration (i.e., proportion of maximum consumption, $C_{\max }$ ) from week 0 - year 0 of the dynamic state variable model. Lengths are a subset of those modeled: (a) $50 \mathrm{~mm},(b) 125 \mathrm{~mm},(c) 275 \mathrm{~mm}$, and (d) $350 \mathrm{~mm}$. Rations are $30 \%$ (circle), $60 \%$ (square), and $90 \%$ (triangle) maximum consumption. At each latitude, length, and ration combination, the variation shown is due to the effects of varying fat reserves $(20,60,100 \%$ of maximum) and reproductive tissue $(0,20,60,100 \%$ of maximum $)$ in the model.

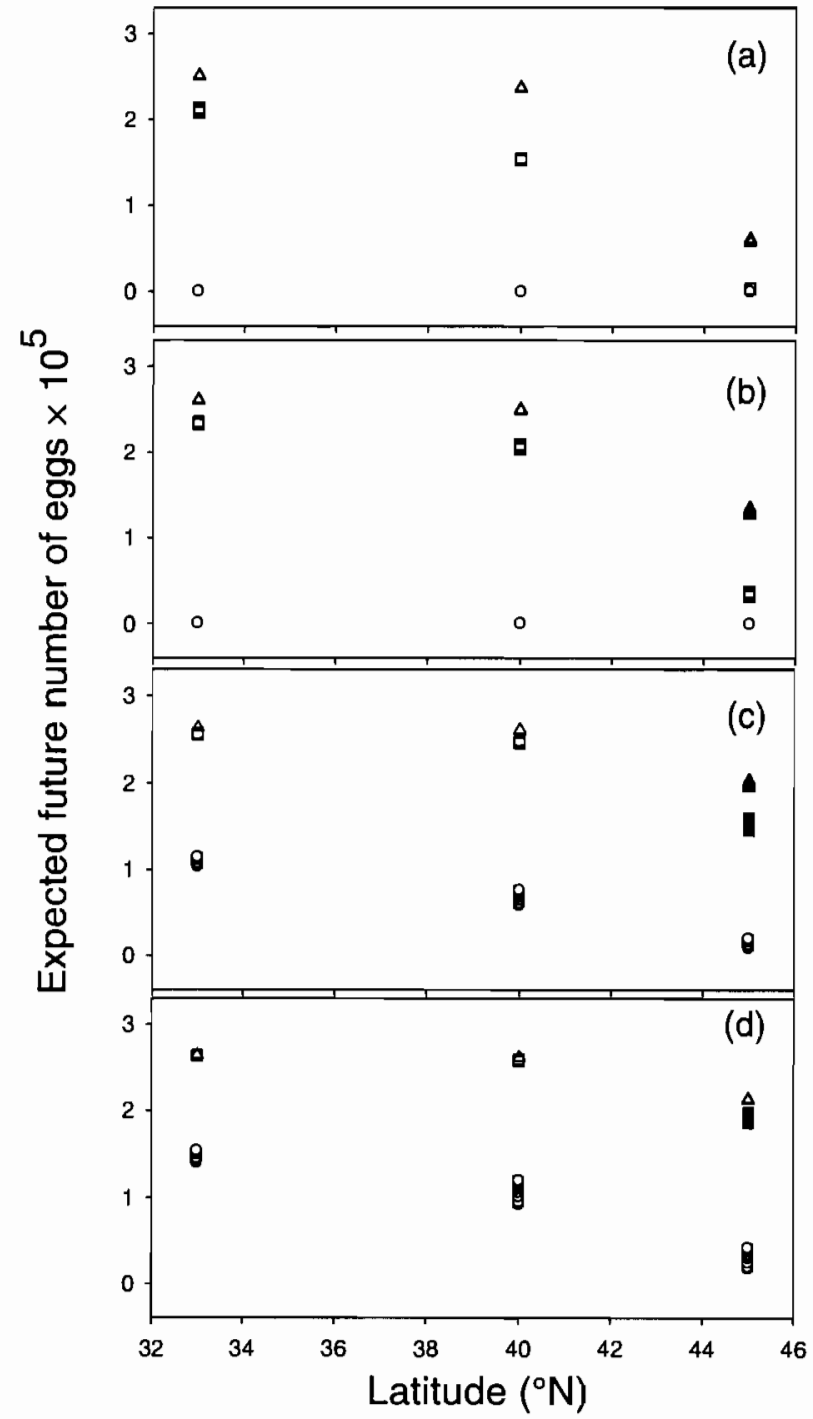

clined with increasing length, regardless of fat reserves (Fig. 3a). At an intermediate ration, a similar pattern emerged for the southern latitude (Fig. $3 b$, top panel). However, proportionally more energy was allocated to length with higher fat reserves at higher latitudes (Fig. $3 b$, middle and bottom panels). At the highest ration, fish of all lengths invested considerable energy to length in the south, regardless of fat reserves, whereas a similar pattern only occurred at higher latitudes for fish with the highest fat reserves (Fig. $3 c$ ).
Allocation to fat and reproduction also depended on ration, internal state, and latitude. At the lowest ration, the proportion energy allocated to fat generally increased with length at all latitudes when fat reserves were less than $100 \%$ (Fig. 3d). At higher rations, fat was no longer allocated at any fat reserve level at the southern latitude, whereas the same pattern that occurred at the lowest ration held for higher latitudes and rations (Figs. $3 e, 3 f$ ). A similar general pattern occurred for reproductive tissue. The proportion of energy allocated to reproduction generally increased with length and fat reserves at the lowest ration at all latitudes (Fig. $3 g$ ). Although this pattern held for higher rations at the higher latitudes, allocation to gonads was unrelated to fat at the southern latitude at high consumption (Figs. 3h, 3i).

\section{Simulated growth under optimal allocation}

Length generally increased through time, although the rate of length increase depended on latitude and ration. At $30 \%$ maximum consumption, growth in length was poor at all latitudes, never reaching the critical length for reproduction during 6 years (Fig. 4a). At higher rations, growth in length was higher but declined with increasing latitude (Figs. 4b,4c).

As expected, fat abundance typically cycled annually, although the oscillations depended on latitude and ration. For fat at low rations, reserves at the southern and middle latitudes increased before summer, declined during summer, peaked again before winter, and then declined through the winter (Fig. 4d). Fat reserves of northern largemouth bass at low ration increased during fall and then declined during winter of each year, with no increase before summer (Fig. 4d). Patterns of growth in fat differed at higher rations. Although fat reserves did not cycle seasonally in the south, fat reserves increased in fall and declined in winter at the higher latitudes, with greater seasonal amplitude in the northern latitudes than in middle latitudes (Figs. $4 e, 4 f$ ).

At the lowest ration, growth in reproductive tissue only occurred very late in simulations (Fig. $4 g$ ). At higher rations at all latitudes, reproductive tissue of sexually mature fish generally increased in fall and, by design of the model, fell to zero after spawning on week 51 (Figs. $4 h, 4 i$ ). At the highest ration, fish only partially developed reproductive tissue in fall and then completed ovarian development (i.e., $r=$ 1.0) immediately before spawning in spring (Fig. 4i).

\section{Theoretical reciprocal transplants}

Largemouth bass grew in length faster in the south than in the north, regardless of whether their energy allocation pattern was optimal in the south or the north (Fig. 5a). Southern bass (i.e., those with optimal allocation responses in the south) grew faster than northern bass in both temperature environments (Fig. 5a). Although the difference was minor at northern temperatures, at southern temperatures, southern bass were about $20 \%$ longer than northern bass by age 1 (Fig. $5 a$ ).

Expected lifetime egg production was greater in the south than in the north, regardless of origin of the bass (Fig. $5 b$ ). This latitudinal fitness difference was much smaller for bass from the north than from the south. In the south, energy allocation response made little difference in expected fitness. In northern temperatures, allocation response made a large difference in expected fitness; bass with optimal northern allo- 
Fig. 3. Average proportion of energy allocated to length, fat, and reproductive tissue during fall weeks as a function of fat reserves, length, and latitude in year 0 of the dynamic state variable model. Results for other seasons and subsets of data are not shown.

Largemouth bass (Micropterus salmoides) received 30,60 , or $90 \%$ of maximum consumption $\left(C_{\max }\right)$. Reproductive tissue was at $20 \%$ of maximum. The subset of fat reserve states shown are $20 \%$ (circle), $60 \%$ (square), and $100 \%$ (triangle) of maximum capacity. Latitudes are south $(\mathrm{S})$, middle $(\mathrm{M})$, and north $(\mathrm{N})$.

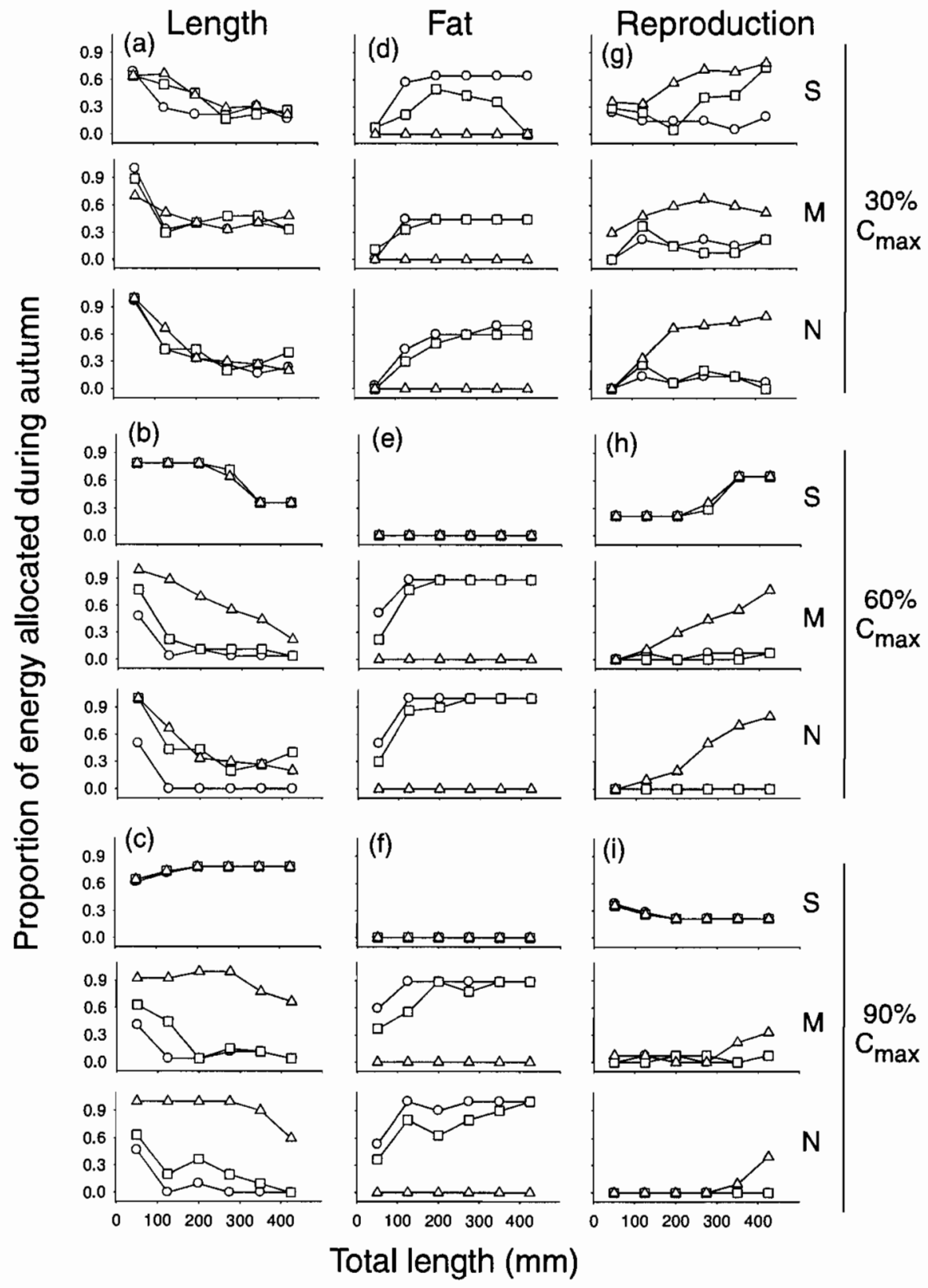

cation responses did much better than those with allocation responses optimal for southern temperatures (Fig. $5 b$ ).

Annual timing of development of ovaries differed between the north and south and between northern and southern bass (Fig. 6). Northern bass in the north began building ovaries earlier in the year than southern bass in the south (Figs. $6 a$, $6 d)$. When northern bass were transplanted to the south, they developed maximum ovary size many months before spawning (Fig. 6b). When southern bass were transplanted to the north, they waited too long within a year to allocate energy to reproduction and never developed enough ovary mass to reproduce (Fig. 6c).

\section{Discussion}

The dynamic state variable model results revealed that latitude, body size, and ration shaped patterns of optimal energy allocation in largemouth bass. Subsequent growth patterns 
Fig. 4. Growth simulation results using optimal energy allocation decisions from the dynamic state variable model. Simulated largemouth bass (Micropterus salmoides) had initial states of $50 \mathrm{~mm}, 20 \%$ fat reserves, and $0 \%$ reproductive tissue and received either 30,60 , or $90 \%$ of maximum consumption under southern $(\mathrm{S})$, middle $(\mathrm{M})$, or northern $(\mathrm{N})$ seasonal temperatures, respectively.

Length

(a)

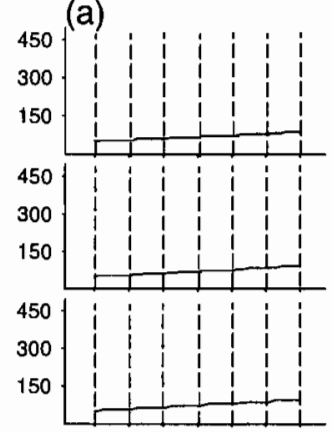

(b)

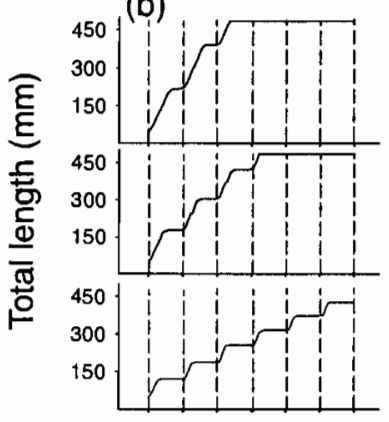

(c)

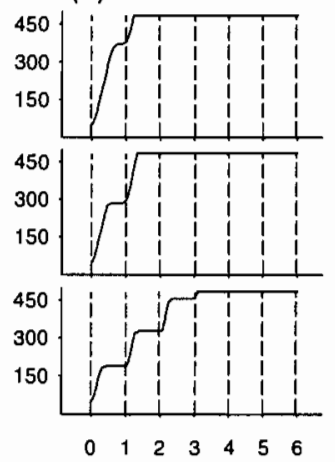

Fat

(d)
Reproduction

(g)

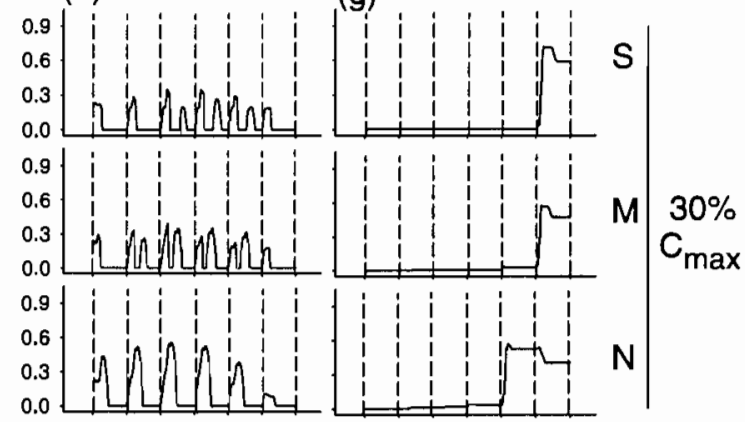

(e)

(h)

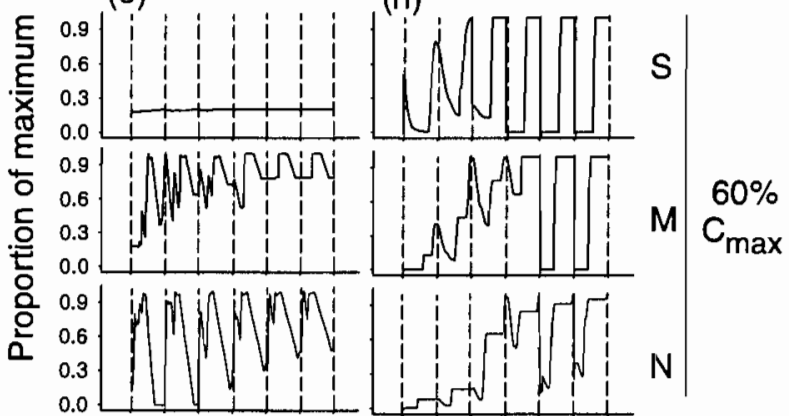

(f)

(i)

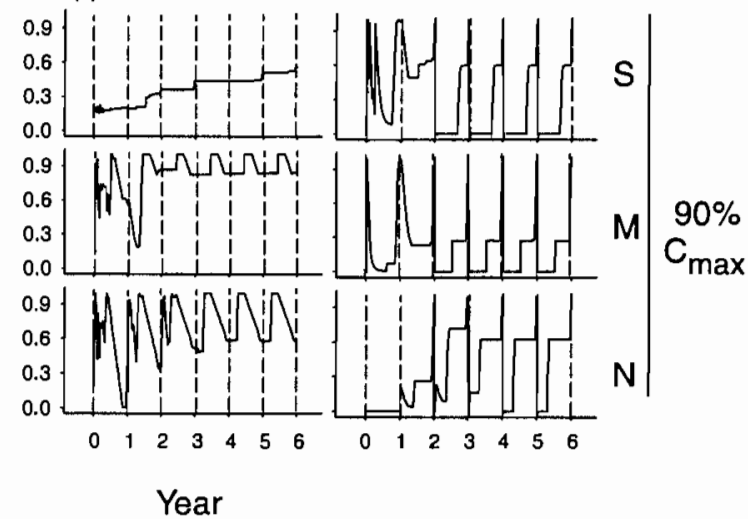

differed across latitudes as a function of these underlying energy allocation decisions. Below, we first explore the underlying allocation and growth patterns and then address their implications for variation in size along latitudinal gradients (i.e., the validity of Bergmann's rule to fish).

\section{Allocation patterns and growth}

Allocation of energy to fat depended on ration, fat reserves, and body size. When ration was restricted to $30 \%$ of maximum, allocation patterns were similar at all latitudes, indicating that selection in low productivity systems should generate similar growth regardless of differences in seasonal temperature. When fat reserves were low at this low ration, the smallest fish allocated to length, whereas large individuals allocated to fat until reserves were filled. For small fish, increasing length should proffer energetic benefits by reducing mass-specific metabolic costs and increasing fat storage capacity, thereby increasing survival during winter when costs exceed intake (Post and Evans 1989; Post and Parkinson 2001). In contrast, larger counterparts should have sufficient fat capacity to store fat and offset winter starvation. When fat reserves were at maximum capacity in the model, energy was still invested in length for small fish but in reproductive tissue for large fish. For large fish with relatively low massspecific metabolic costs and abundant fat, increasing reproductive tissue to ensure spawning following winter was a priority because starvation risk was relatively low.

At higher rations, allocation strategies diverged between the southern and higher latitudes. In the south, allocation to fat reserves was no longer a priority at any size because con- 
Fig. 5. (a) Length at age 1 and (b) expected lifetime fitness (number of eggs) arising from theoretical reciprocal transplants as a function of latitude. Origin of modeled largemouth bass (Micropterus salmoides) is either south (solid circle) or north (open circle) and growth environment is representative of either northern or southern temperatures, as indicated on the graphs. Simulated largemouth bass had initial states of $50 \mathrm{~mm}, 20 \%$ fat reserves, and $0 \%$ reproductive tissue and received $90 \%$ of maximum consumption.

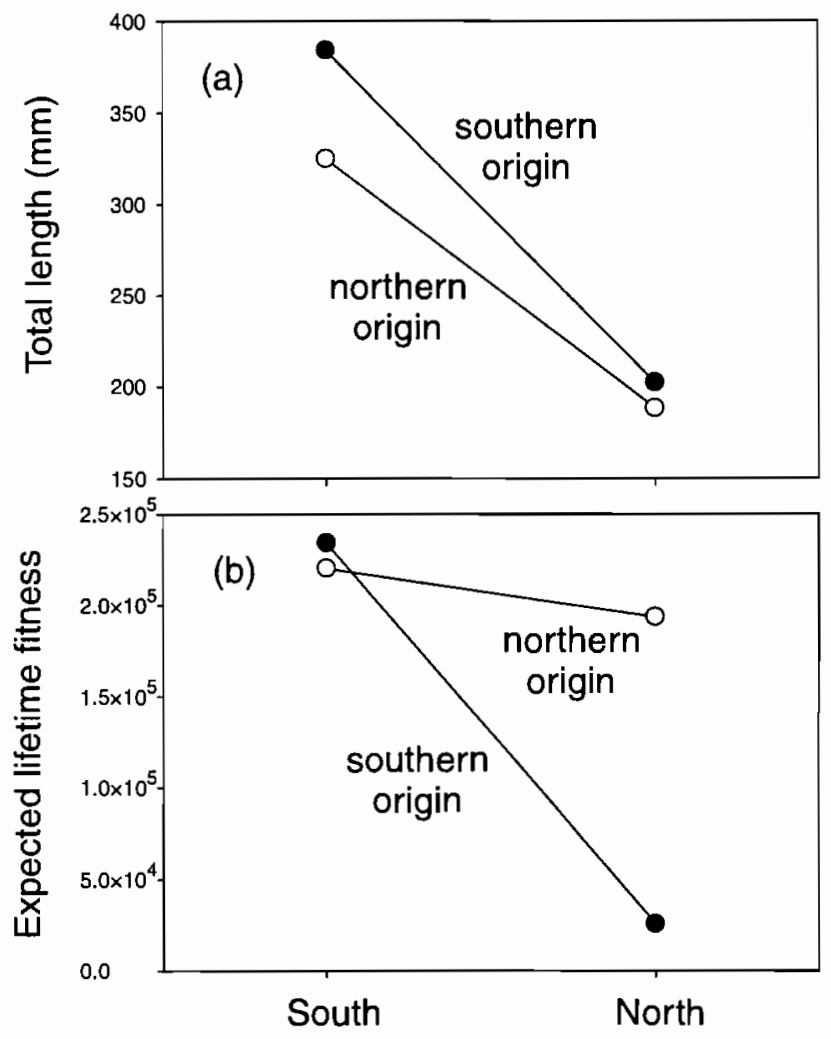

Latitude

sumption always exceeded metabolic needs. More energy was diverted to growth in length in small individuals and reproductive tissue in large counterparts, ensuring high growth rates, large sizes, and high future reproductive output. At higher latitudes, increased ration exerted little change on energy allocation patterns relative to patterns at low ration. Anticipation of winter metabolic costs posed similar constraints on growth, regardless of increased caloric intake during warm months. In total, these predicted results are congruent with the prediction by Shul'man (1974) that seasonal changes in energy reserves of fish should increase with increasing seasonal differences in temperature and photoperiod. Indeed, northern populations of another widely distributed species, Atlantic silversides (Menidia menidia), fatten in fall, but southern ones do not (Schultz and Conover 1997). In addition, age-0 largemouth bass originating from Alabama, Ohio, and Wisconsin populations reared under identical experimental conditions in Ohio during summer 1994 had fall whole-body energy densities that were consistent with the patterns in our model predictions: Wisconsin and Ohio individuals had $13 \%$ higher energy densities than Alabama counterparts (see table 1 of Fullerton et al. 2000).

\section{Adaptive significance}

There is always the risk with optimality models that although the model returns optimal strategies, the optimal strategies may produce fitness consequences that are not very different from other strategies. From the theoretical reciprocal transplants, we saw that southern conditions did not drive a strong relationship between allocation response and expected fitness. Individuals in the south could survive and reproduce regardless of whether their allocation responses were adapted to the south or the north, suggesting that optimal strategies may not be important for maintaining high fitness at this latitude. In contrast, conditions in the north were harsh enough that only individuals with allocation responses adapted to that particular environment were able to survive and reproduce there. Thus, we should expect stronger selection for optimal energy allocation responses in the north than in the south.

For all life stages, latitudinal adjustments in energy allocation responses ensured high expected future reproductive output up to some threshold latitude (i.e., the middle latitude). Beyond this latitude, expected fitness of small individuals declined more than large counterparts, even at high rations. Thus, the model supports the contention that insufficient fat reserves during winter and reduced growth with a short growing season may limit early survival and thus the northern extent of largemouth bass and other species, despite energetic adjustments (Garvey et al. 1998; Schultz et al. 1998). Northern latitude temperatures used in our model derive from a lake near the northern limit of largemouth bass (MacCrimmon and Robbins 1975), suggesting that the model captured the primary conditions that affect expected reproduction through negative effects on small, young fish. Similarly, a bioenergetics model predicted that low temperatures limit the northern extent of smallmouth bass ( $M$. dolomieu) (Shuter et al. 1980; Shuter and Post 1990), primarily by limiting growth and survival of offspring.

\section{Latitudinal patterns in body size}

In our model, fish grew more rapidly in length at low latitudes than at high latitudes and, thus, were larger in the south than the north at any age before they reached maximum size. This is in agreement with the converse to Bergmann's rule, which has been observed in other poikilotherms (Masaki 1978; Mousseau and Roff 1989), but is in conflict with what apparently is the more common pattern of an increase in size with increasing latitude in poikilotherms, including protists, plants, and animals (see review by Atkinson (1994); Arnett and Gotelli 1999). In our model, latitudinal differences in size-at-age arose both as a simple consequence of temperature dependence of consumption and metabolic rates and as an optimal allocation response to expected temperature patterns. Both pathways produced larger fish at southern latitudes than at northern latitudes, thus supporting the converse to Bergmann's rule. A field pattern for first-year growth in largemouth bass also generally confirms this pattern in that individuals in southern populations reach larger sizes by their first fall than those in northern ones (Garvey et al. 2003). 
Fig. 6. Proportion of maximum reproductive mass (ovaries) in simulated largemouth bass (Micropterus salmoides) from theoretical reciprocal transplants using optimal energy allocation decisions from either northern- or southern-origin largemouth bass. The growth environment was representative of either northern or southern temperatures, as indicated on the graphs. Simulated largemouth bass had initial states of $50 \mathrm{~mm}, 20 \%$ fat reserves, and $0 \%$ reproductive tissue and received $90 \%$ of maximum consumption.

\section{South latitude North latitude}

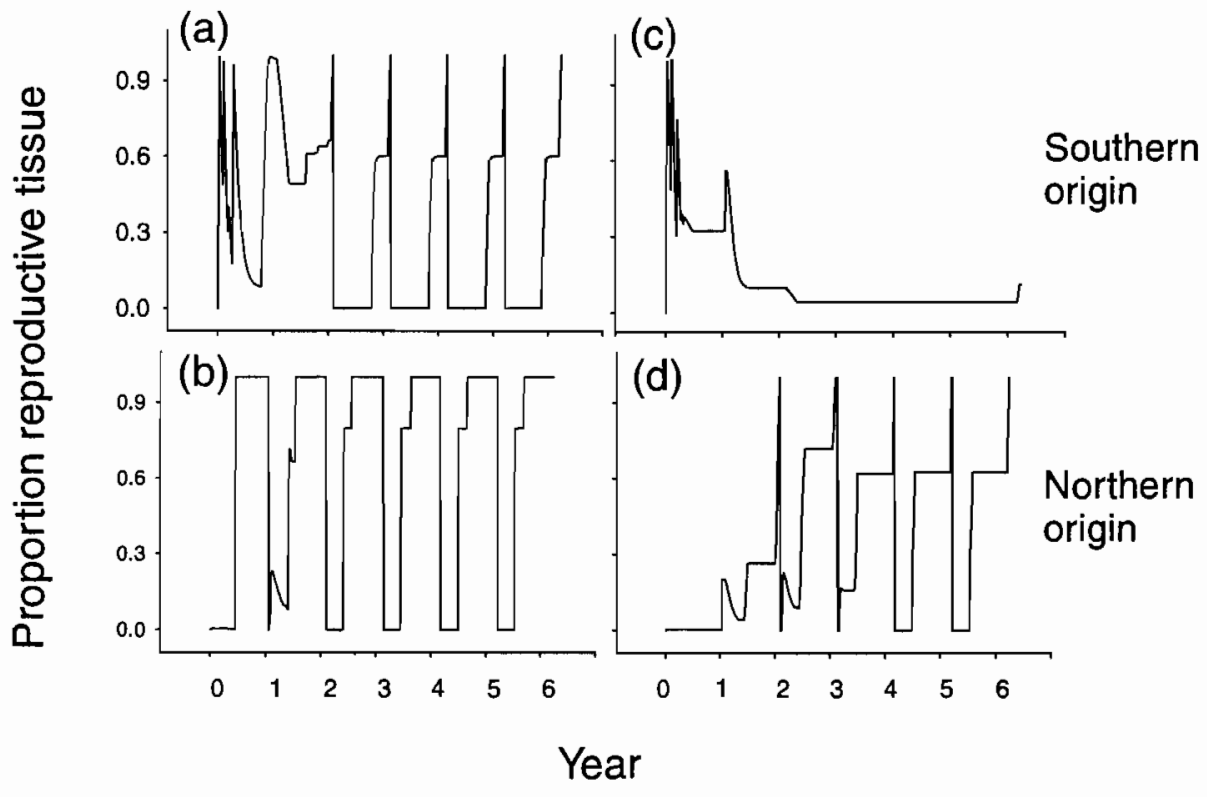

\section{Other adaptations}

In addition to modifying patterns of energy allocation, other adaptations may enhance expected fitness as the length of the growing season declines and the duration of winter increases with latitude. Our model predicted that small $(<125 \mathrm{~mm})$ largemouth bass at northern latitudes receiving moderate rations should have a low total reproductive output over the next 6 years. Because largemouth bass often do not reach sizes $>125 \mathrm{~mm}$ by the end of their first year in these systems (Garvey et al. 2003), other adaptive mechanisms must be in place to ensure persistence. One apparent adjustment would be to increase life span and reproductive frequency and thereby enhance lifetime reproductive output (Leggett and Carscadden 1978). Strong selection for rapid early growth rates through pathways not explored in the current model (e.g., increased foraging activity, increased assimilation efficiency) also may occur (Nicieza et al. 1994; Jonassen et al. 2000). Indeed, many widely distributed species at high latitudes have genotypes that allow them to grow more rapidly during the first year of life to counteract the shortened growing season (i.e., countergradient variation; Conover and Schultz 1995). For example, young Menidia (Lankford et al. 2001), striped bass (Morone saxatilis; Conover et al. 1997), and many other species (Conover 1990) have faster early growth rates in the north than the south, in contrast to our results.

Although not explicitly explored by our model, fish at high latitudes may reduce levels of activity and metabolic rates in the winter to reduce energetic demands for limited fat reserves during winter. Comparing predictions from massbalance bioenergetics models for age- 0 largemouth bass with growth results from overwinter pool experiments demonstrated that conventional allometric relationships used in these models overestimate energetic costs (Wright et al. 1999). Another experiment comparing winter growth across three simulated winters (i.e., low, middle, and high latitudes) revealed that small largemouth bass expend proportionately less energy during winter fasting under high-latitude seasonal temperatures than low-latitude winter conditions (Fullerton et al. 2000). Seasonal variation in body composition predicted by our model combined with additional adaptations likely allow largemouth bass to persist at latitudes higher than those predicted by simple relationships between temperature and somatic growth.

Other unexplored adaptations may exist. Although the model predicted that fish at southern latitudes typically invest energy into growth in length and not fat reserves, predatorinduced foraging risk may vary inversely with latitude, with inherently riskier foraging occurring in the south (Garvey et al. 2003; also see Lankford et al. 2001). If this is true, then southern individuals may store fat reserves, reduce foraging, and ultimately reduce the rate of somatic growth when foraging is particularly risky. This scenario may be further complicated if predation risk is size-dependent in that individuals increase their survival probability by growing in length (Christensen 1996). Resolving trade-offs among risky foraging, inactivity, and energy allocation may depend on interactions among size-dependent predation, refuge, temperature, and food availability, which were not included in our model. Another option not explored in the model was flexible allocation of eggs to ovaries. Variation in fecundity at a given length may increase adaptive options for large- 
mouth bass, influencing patterns of growth and expected lifetime fitness.

\section{Implications}

By exploring how seasonal variation in temperature interacts with the bioenergetics of fish, we discovered that increasing latitude should reduce the reproductive potential of aquatic poikilotherms. Although this finding is not particularly novel in itself, the nonlinear decline in expected fitness for largemouth bass suggests a dramatic reduction in population viability with a slight increase in latitude beyond some threshold. The two relatively distinct energy allocation strategies that arose suggest that two general options exist. In anticipation of low ration and high metabolic demands, an animal should store fat and begin building ovaries early in the reproductive year. If large energetic deficits are improbable, as they may be at low latitudes and high productivities, then they should increase length when small and wait longer within a reproductive year to begin building ovaries. When modeled largemouth bass with allocation responses that were optimal in the south were transplanted to the north, they actually grew in length more rapidly than did northern-adapted bass in their native environment. But these southern fish grew in length at the expense of not adding fat and not beginning early allocation to ovaries and were thus ultimately unsuccessful in the north. Early allocation to ovaries within a year is commonly observed in organisms facing low productivity later in the year immediately before spawning season (Bunnell and Marschall 2003).

Our model was built with seasonal temperature patterns that remained constant from year to year. We expect that optimal allocation strategies may also respond to predictability of these patterns (Roff 1992; Winemiller and Rose 1992). Middle latitudes may be less predictable in their seasonal temperatures than northern or southern latitudes. Bunnell and Marschall (2003) have shown that even a low chance of an unproductive spring makes optimal timing of allocation to reproduction similar to that in conditions in which spring is always harsh. Thus, we may expect some middle-latitude allocation patterns to be more similar to northern ones if environmental predictability is important.

Stocking fish is a common practice in fisheries management, with several goals including enhancing naturally reproducing populations, increasing sportfish diversity, and controlling nuisance prey species (Heidinger 1999). Although this practice is justifiable under certain circumstances (Conover 1998), our modeling results and much experimental work clearly demonstrate that fish within populations often accumulate adaptations that increase their local fitness but may prove maladaptive in new situations (also see Munch and Conover 2002). For example, we have shown that allocation responses that are optimal in the south may be unsuccessful in the north. Understanding whether these adaptations are important at extremely local scales (e.g., within individual lakes) or larger ones (e.g., within- or among-latitudes) becomes important because the introduction of genotypes with suboptimal traits into novel populations may be deleterious through the effects of outbreeding depression (Philipp 1992; Conover 1998). Hypothesis generation through modeling combined with reciprocal transplant or common garden ex- periments will allow us to ascertain the geographic scale by which important adaptations arise. From this, we may generate appropriate conservation guidelines for stocking and other management practices that depend on knowledge of fish growth and energetic condition.

\section{Acknowledgements}

We thank two anonymous reviewers for their helpful comments. A National Science Foundation grant (NSF-EPSCoR) through the $\mathrm{K}^{*}$ Star First Award program and a Creative Research Award through the Southern Illinois University Office of Research and Development supported part of this work.

\section{References}

Arnett, A.E., and Gotelli, N.J. 1999. Geographic variation in lifehistory traits of the ant lion, Myrmeleon immaculatus: evolutionary implications of Bergmann's Rule. Evolution, 53: 1180-1188.

Atkinson, D. 1994. Temperature and organism size - a biological law for ectotherms? Adv. Ecol. Res. 25: 1-58.

Bellman, R. 1957. Dynamic programming. Princeton University Press, Princeton, N.J.

Bunnell, D.B., and Marschall, E.A. 2003. Optimal energy allocation to ovaries after spawning. Evol. Ecol. Res. 5: 439-457.

Carlander, K.D. 1977. Handbook of freshwater fishery biology. Vol. II. Iowa State Press, Ames, Iowa.

Christensen, B. 1996. Predator foraging capabilities and prey antipredator behaviours: pre- versus postcapture constraints on sizedependent predator-prey interactions. Oikos, 76: 368-380.

Conover, D.O. 1990. The relation between capacity for growth and length of growing season: evidence for and implications of countergradient variation. Trans. Am. Fish. Soc. 119: 416-430.

Conover, D.O. 1998. Local adaptation in marine fishes: evidence and implications for stock enhancement. Bull. Mar. Sci. 62: 477-493.

Conover, D.O., and Schultz, E.T. 1995. Genotypic similarity and the evolutionary significance of countergradient variation. Trends Ecol. Evol. 10: 248-252.

Conover, D.O., Brown, J.J., and Ehtisham, A. 1997. Countergradient variation in growth of young striped bass (Morone saxatilis) from different latitudes. Can. J. Fish. Aquat. Sci. 54: 2401-2409.

Fullerton, A.H., Garvey, J.E., Wright, R.A., and Stein, R.A. 2000. Overwinter growth and survival of largemouth bass: interactions among size, food, origin, and winter duration. Trans. Am. Fish. Soc. 129: 1-12.

Garvey, J.E., Wright, R.A., and Stein, R.A. 1998. Overwinter growth and survival of age- 0 largemouth bass: revisiting the role of body size. Can. J. Fish. Aquat. Sci. 55: 2414-2424.

Garvey, J.E., DeVries, D.R., Wright, R.A., and Miner, J.G. 2003. Energetic adaptations along a broad latitudinal gradient: implications for widely distributed communities. Bioscience, 53: 141-150.

Heidinger, R.C. 1999. Stocking for sport fisheries enhancement. In Inland fisheries management in North America. 2nd ed. Edited by C.C Kohler and W.A. Hubert. Am. Fish. Soc. Spec. Publ., Bethesda, Md. pp. 375-401.

Jonassen, T.M., Imsland, A.K., Fitzgerald, R., Bonga, S.W., Ham, E.V., Naevdal, G., Stefansson, M.O., and Stefansson, S.O. 2000. Geographic variation in growth and food conversion efficiency of juvenile Atlantic halibut related to latitude. J. Fish Biol. 56: 279-294.

Lankford, T.E., Billerbeck, J.M., and Conover, D.O. 2001. Evolution of intrinsic growth and energy acquisition rates. II. Trade- 
offs with vulnerability to predation in Menidia menidia. Evolution, 55: 1873-1881.

Leggett, W.C., and Carscadden, J.E. 1978. Latitudinal variation in reproductive characteristics of American shad (Alosa sapidissima): evidence for population specific life history strategies in fish. J. Fish. Res. Board Can. 35: 1469-1478.

Lindsey, C.C. 1966. Body sizes of poikilotherm vertebrates at different latitudes. Evolution, 20: 456-465.

Ludsin, S.A., and D.R. DeVries. 1997. First-year recruitment of largemouth bass: the inter-dependency of early life stages. Ecol. Appl. 7: 1024-1038.

MacCrimmon, H.R., and Robbins, W.H. 1975. Distribution of the black basses in North America. In Black bass biology and management. Edited by R.H. Stroud and H. Clepper. Sport Fishing Institute, Washington, D.C. pp. 56-66.

Mangel, M., and Clark, C.W. 1988. Dynamic modeling in behavioral ecology. Princeton University Press, Princeton, N.J.

Masaki, S. 1978. Seasonal and latitudinal adaptations in the life cycles of crickets. In Evolution of insect migration and diapause. Edited by H. Dingle. Springer Verlag, New York. pp. 72-100.

Miranda, L.E., and Hubbard, W.D. 1994. Length-dependent winter survival and lipid composition of age- 0 largemouth bass in Bay Springs Reservoir, Mississippi. Trans. Am. Fish. Soc. 123: 80-87.

Mousseau, T.A. 1997. Ectotherms follow the converse to Bergmann's Rule. Evolution, 51: 630-632.

Mousseau, T.A., and Roff, D.A. 1989. Adaptation to seasonality in a cricket: patterns of phenotypic and genotypic variation in body size and diapause expression along a cline in season length. Evolution, 43: 1483-1496.

Munch, S.B., and Conover, D.O. 2002. Accounting for local physiological adaptation in bioenergetic models: testing hypotheses for growth rate evolution by virtual transplant experiments. Can. J. Fish. Aquat. Sci. 59: 393 403 .

Nicieza, A.G., Reiriz, L., and Brana, F. 1994. Variation in digestive performance between geographically disjunct populations of Atlantic salmon: countergradient in passage time and digestion rate. Oecologia, 99: 243-251.

Niimi, A.J., and Beamish, F.W.H. 1974. Bioenergetics and growth of largemouth bass (Micropterus salmoides) in relation to body weight and temperature. Can. J. Zool. 52: 447-456.

Oster, R.A. 2002. Winter and early spring mortality and lipid composition of age- 0 largemouth bass at a mid latitude. M.Sc. thesis, Southern Illinois University, Carbondale, Ill.

Partridge, L., and Coyne, J.A. 1997. Bergmann's Rule in ectotherms: is it adaptive? Evolution, 51: 632-635.

Philipp, D.P. 1992. Stocking Florida largemouth bass outside its native range. Trans. Am. Fish. Soc. 121: 686-691.

Post, J.R., and Evans, D.O. 1989. Size-dependent overwinter mortality of young-of-year yellow perch (Perca flavescens): laboratory, in situ enclosure, and field experiments. Can. J. Fish. Aquat. Sci. 46: $1958-1968$.

Post, J.R., and Parkinson, E.A. 2001. Energy allocation strategy in young fish: allometry and survival. Ecology, 82: 1040-1051.

Press, W.H., Teukolsky, S.A., Vetterling, W.T., and Flannery, B.P. 1992. Numerical recipes in $\mathrm{C}$ : the art of scientific computing. Cambridge University Press, New York.

Rice, J.A., and Cochran, P.A. 1984. Independent evaluation of a bioenergetics model for largemouth bass. Ecology, 65: 732-739.

Rice, J.A., Breck, J.E., Bartell, S.M., and Kitchell, J.F. 1983. Evaluating the constraints of temperature, activity and consumption on growth of largemouth bass. Environ. Biol. Fishes, 3: 263-275.

Roff, D.A. 1980 . Optimizing development time in a seasonal environment: the "ups and downs" of clinal variation. Oecologia, 45: 202-208.

Roff, D.A. 1986. Predicting body size with life history models. Bioscience, 36: 316-323.

Roff, D.A. 1992. Evolution of life histories: theory and analysis. Chapman and Hall, New York.

Shul'man, G.E. 1974. Life cycles of fish. John Wiley and Sons Inc., New York.

Schultz, E.T., and Conover, D.O. 1997. Latitudinal differences on somatic energy storage: adaptive responses to seasonality in an estuarine fish (Atherinidae: Menidia menidia). Oecologia, 109: 516-529.

Schultz, E.T., Conover, D.O., and Ehtisham, A. 1998. The dead of winter: size-dependent variation and genetic differences in seasonal mortality among Atlantic silverside (Atherinidae: Menidia menidia) from different latitudes. Can. J. Fish. Aquat. Sci. 55: $1149-1157$.

Shuter, B.J., and Post, J.R. 1990. Climate, population viability, and the zoogeography of temperate fishes. Trans. Am. Fish. Soc. 119: $314-336$.

Shuter, B.J., MacLean, J.A., Fry, F.E.J., and Regier, H.A. 1980. Stochastic simulation of temperature effects on first-year survival of smallmouth bass. Trans. Am. Fish. Soc. 109: 1-34.

Trebitz, A.S. 1991. Timing of spawning in largemouth bass: implications of an individual-based model. Ecol. Model. 59: 203-227.

Weatherley, A.H., and Gill, H.S. 1987. The biology of fish growth. Academic Press, London.

Winemiller, K.O., and Rose, K.A. 1992. Patterns of life-history diversification in North American fishes: implications for population regulation. Can. J. Fish. Aquat. Sci. 49: 2196-2218.

Wright, R.A., Garvey, J.E., Fullerton, A.H., and Stein, R.A. 1999. Using bioenergetics to explore how winter conditions affect growth and consumption of age-0 largemouth bass. Trans. Am. Fish. Soc. 128: $603-612$. 